\title{
Exploring divergent aspects of middle-of-the-pyramid consumers' dining experience
}

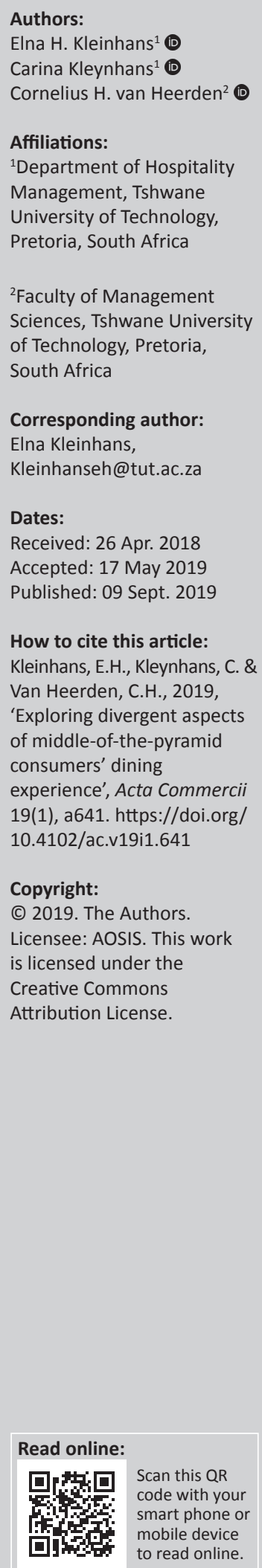

Orientation: This study seeks to identify the most important dimensions related to restaurant dining among middle-of-the-pyramid consumers.

Research purpose: This article aims to determine the expectations of South African middle-ofthe-pyramid (MOP) consumers during a dining experience.

Motivation for the study: To develop an up-market segmentation framework that will assist restaurateurs to reposition themselves to better understand the needs of MOP consumers.

Research design, approach and method: Both qualitative and quantitative methods were followed. The sample in the study consisted of 18 interviewees and 363 respondents selected from full-service restaurants in Gauteng Province. Exploratory factor analysis with varimax rotation was used to analyse the dining experience dimension items, and confirmatory factor analysis was performed to achieve the objective of the study. Qualitative data was analysed using a constant comparative method. Confirmed themes and patterns were determined by the frequency with which each was mentioned for similarities, differences and general patterns.

Main findings: The results show that on a six-point Likert scale, the commonality between the various dining experience dimensions was relatively high, ranging from 0.377 to 0.768 . The dining experience dimension items yielded eight factors that were interpretable. The coefficient alpha varied between 0.69 and 0.92 for all eight dining experience dimensions. The eight underlying dimensions (service, social, food, layout, restaurant health, atmosphere, food health and accessibility) are independent variables that influence MOP consumers in their choice with respect to dining out, but each dining experience dimension has a particular level of importance.

Practical/managerial implications: The findings of this research have implications for the restaurant industry. Restaurateurs targeting this MOP customer segment should do so by using a unique marketing mix that applies the eight dimensions identified in this study to this segment's dining experience.

Contribution/value-add: This article offers the South African restaurant service sector increased insight into the South African MOP market segment's dining behaviour, and proposes and confirms the implications for their expected dining experience dimensions.

Keywords: dining behaviour; dining experience dimensions; restaurant expectations; middleof-the-pyramid consumers; South Africa.

\section{Introduction}

The rapidly growing black middle class, referred to as middle-of-the-pyramid (MOP) consumers, has been one of the most noticeable phenomena in post-apartheid society, and has played an important role in reshaping the South African society (Lappeman \& Neethling 2017). They tend to attract researchers as a result of possible new theoretical and practical contributions in relation to international trends in the buying behaviour of this segment (African Development Bank 2011). Middle-of-the-pyramid consumers have grown to become a major market in countries such as Brazil, Russia, India, China and South Africa (BRICS) (Asian Development Bank 2010). Growth has also been noted in countries in sub-Saharan Africa, South Asia, East Asia and Latin America (African Development Bank 2011). The size of the MOP market differs between countries and regions, and is responsible for greater demand for, and consumption of, consumer products (Kravets \& Sandikci 2014). The movement of South African marketers to focus on the more prosperous segments is reflected in similar trends in emerging markets in developing countries, but the growing MOP is more composite because of the diversity of the market and its 'cultural paradox' and heterogeneous nature (Potgieter, Wiese \& Strasheim 2013). This market segment is still underestimated and sometimes overlooked by marketers, especially in leisure behaviour and consumption (Kruger \& Saayman 2014). Similarly, research on the factors that influence MOP 
consumers' buying behaviour in sub-Saharan Africa is still limited (Jackson 2016).

The purpose of this exploratory research was therefore to explore the limited knowledge in the current South African MOP dining experience literature by determining the expectations of MOP consumers when dining out at fullservice restaurants. This information is invaluable for the hospitality sector in that it will allow restaurateurs to target this local emerging market segment in an improved manner.

\section{Literature review Middle-of-the-pyramid market segment}

The rise of the MOP in Africa has resulted in new markets. Chickweche and Fletcher (2014) support other researchers who have addressed the influence of emerging markets, and note that they also refer to the South African middle class consumer and 'black diamonds' as the MOP (Kolk, RiveraSantos \& Rufin 2014).

Economic opportunities have resulted in black people earning higher income levels and showing growth in spending power. As mentioned by Korhonen (2018), South Africa's MOP market segment has doubled in number to 6 million over the last 5 years, and accounts for a third of the total consumption expenditure of the country (Venter, Chinomona \& Chuchu 2016). According to Business Tech (2016), the spending power of South African black people trebled, while the spending power of white people remained the same over 12 years. Since 2014, MOP consumers are responsible for $67 \%$ of the total spending power of the black people, and about $40 \%$ of total consumer spending power in South Africa (Simpson \& Ramogase 2014). This has contributed to an upturn in their dining out behaviour (Chickweche \& Fletcher 2014). The MOP has been segmented by the updated 14-segment Living Standards Measure (LSM) model (Strydom 2011), but the particular needs and aspirations of MOP consumers regarding the dining out behaviour (Chickweche \& Fletcher 2014) because of lifestyle and particular consumer behaviour should be reassessed (Kruger \& Saayman 2014). Previous studies on the MOP market potential of the domestic South African market have been conducted in fields such as wine consumption (Du Toit 2011; Ndanga, Louw \& Van Rooyen 2010; Opperman 2010), consumer/buying behaviour (Bevan-Dye, Garnett \& De Klerk 2012; Chickweche \& Fletcher 2014; Goldberg \& Jansen van Rensburg 2013; Kruger \& Saayman 2014, 2016; Potgieter et al. 2013), advertising (Johnson 2013) and other business industries (Goldberg 2011; Van Loggerenberg 2009).

Limited research has been done in South Africa on MOP consumers' dining needs and expectations or on their most important dining experience dimensions (Moolman 2011; Petzer \& Mackay 2014). The findings of this research have implications for the restaurant industry. Restaurateurs targeting this MOP customer segment should do so by using a unique marketing mix that applies the eight dimensions identified in this study to this segment's dining experience.

\section{The dining experience}

The restaurant industry is recognised as one of six major industries in the hospitality sector and as a part of the service industry (Parsa et al. 2012). The food and beverage industry in South Africa is showing positive growth, with the value of sales reaching R28.8 billion in 2015 (Day, Immelman \& Roberts-Lombard 2017). To increase service quality in the restaurant industry, Pizam, Shapoval and Ellis (2016) suggest that the industry set measures in place to improve service and product quality based on a clear awareness and understanding of consumer expectations. As such, there is a greater demand for restaurants to create an environment to satisfy customer needs and expectations in a competitive manner (Namkung \& Jang 2010). As stated by Mhlanga and Machingambi (2016), it is imperative for restaurants to offer a level of service that meets or, even better, exceeds consumer expectations (Kruger \& Saayman 2016).

Evaluating someone's dining experience is complex because it is not the result of a single variable, but is rather a phenomenon that is influenced by several independent dimensions (Pantelidis 2010). When dining out, consumers assess their overall experience not only on the basis of the quality of food and drink, but also according to certain dimensions such as the quality of service and the restaurant environment. Therefore, the dining experience consists of a combination of tangible and intangible quality dimensions (Kivits, Stierand \& Wood 2011). As the desire for food increases, consumers tend to set standards for any developing decision-making process with regard to dining according to their needs (biological, cultural and socio-psychological) and in relation to their knowledge of the availability and location of a restaurant (Kivits et al. 2011).

However, the importance of dining experience dimensions and the relationship between these dimensions in relation to South African consumers' satisfaction when dining out has yet to be considered (Kruger \& Saayman 2016). It is therefore extremely important to understand customer needs and to take measures to address or exceed these (Mashaba \& Wiese 2016). Only limited research has been done in South Africa on consumer dining needs and only on the most important dining experience dimensions, such as food, service and atmosphere (Mhlanga \& Tichaawa 2016). Thus, there is a need to conduct research that considers a more comprehensive range of dining experience dimensions. This study focuses specifically on determining those dining experience dimensions pertinent to the MOP consumer segment in South Africa.

\section{Methodology}

The study design comprised both qualitative (to develop and refine the measuring instrument) and quantitative methods (to collect the data from the MOP consumers) to enrich the quality of the research, and to assess consumer expectations of the dining experience (Cresswell \& Clark 2011). 


\section{Instrument development}

Following the example of Kleinhans, Van Heerden and Kleynhans (2016), a review of the literature on important dining experience dimensions and items over a period of 30 years was done to ensure validity and reliability of the study. Several research engines were identified that have proved to be most popular when articles on dining experience dimensions for restaurants are sought (EBSCOhost, ProQuest, ElservierBV, Emerald Group Publishing Limited, Sage and Scopus). Basic terms used in the search included 'dining experience dimensions', 'consumer expectations for restaurants' and 'restaurant service quality'. Initially, 130 studies were retrieved for the period between 1985 and 2015. Despite the variations in dining experience dimensions, numerous studies confirm food quality, service quality and atmosphere as the most important dining experience dimensions. However, new dining experience dimensions have been added to the three basic dining experience dimensions for an assessment of the dining experience, namely, price health/cleanliness and social factors (Kleinhans et al. 2016) (see summary in Table 1).

Several measuring instruments with different dining experience dimensions and variables were noted because a great deal of the research in hospitality focuses on the development of reliable instruments for measuring the constructs. Instruments identified included SERVQUAL (Parasuraman, Zeithaml \& Berry 1985), SERVPERF (Cronin \& Taylor 1992), DINESERV (Stevens, Knutson \& Patton 1995), TANGSERV (Raajpoot 2002), SERVICESCAPE (Reimer \& Kuehn 2005), HOLSERV (Wong et al. 1999), CLEANSAT (Barber \& Scarcelli 2010), DINEX (Antun et al. 2010) and Five Aspects Meal Model (FAMM) (Andersson \& Mossberg 2004; Kivits et al. 2011). These measuring instruments have been applied in previous restaurant research but have limitations in terms of their generic approach, and were therefore deemed unsuitable for this study.

Given that the consumer is part of the experience and the context within which the experience takes place (Gerdes, Stringam \& Brookshire 2008), the researcher first determined customer needs and expectations regarding the dining experience by means of personal interviews $(n=18)$, as shown in Figure 1, considering the set criteria for South African MOP consumers as seen in South African Audience Research Foundation-All Media and Products Study (SAARFAMPS) (2012). During the interviews, the respondents' needs and expectations related to dining out were explored.

An interview schedule guided the researcher in organising and analysing the interview data, and also ensured the reliability of the quality of the interview content and the measuring instrument used (Bowen 2005). The interview schedule was guided by the interview question (what would you describe as important for a dining experience) which was asked until the same answer was repeated a number of times. The number of interviews to be conducted was guided by a continuous data analysis process, based on satisfactory saturation of theoretical categories through the data analysis.
Saturation was reached at 15 and, therefore, three more interviews were done to ensure saturation (Hennink, Hutter \& Bailey 2011; Suri 2011). The data from the interviews were transcribed and analysed by the researcher using a constant comparative method. Confirmed themes and patterns were determined by the frequency with which each was mentioned (see Table 1). This was done by comparing the interview data for similarities, differences and general patterns (Bowen 2005; Gerdes et al. 2008). The data captured from the subjective realities and experiences of the respondents were coded by the researcher. The coding was based on the transcribed interviews (Arora 2012; Hennink et al. 2011).

Content analysis was performed on the important dimensions identified in the interviews. The analysis confirmed that food, atmosphere and service are the main dining experience dimensions of the restaurant experience as guidelines for service quality in the restaurant industry. The items identified are explained in Table 1. For the purpose of this paper, the interviews (qualitative approach) were only used to develop the measurement instrument, and therefore not discussed in the results.

The in-depth description of the study, population, the outcome of the interviews and in-depth literature review ensure that the research is credible and has internal validity. The process allowed the researcher to identify and narrow down the important dining experience dimensions according to consumers' needs and their expectations of the dining experience. A semi-structured questionnaire was developed to reveal the dining needs and expectations of MOP consumers in South Africa.

The DINEX scale (Antun et al. 2010) is known as a broad yet 'parsimonious' scale for measuring restaurant guest expectations of importance. The scale was designed to be used in both qualitative and quantitative methods. This resulted in the use of a customised DINEX scale as the basis to address the objectives and setting of the research. To finalise the questionnaire, the researcher combined the dimensions of DINEX (Antun et al. 2010) (food, service and atmosphere, health and social), literature view and results of the interviews (Table 1). The dimensions for the questionnaire were food (11 items), service (11 items), atmosphere (17 items), social (9 items) and health ( 2 items). The respondents in this study were asked to select the importance of dining experience dimension items on a six-point Likert scale that varied from 'not at all important' (1) to 'extremely important' (6). The researcher had some concerns about a five-point Likert scale, namely that the presence of the mid-point tends to result in misrepresentation in the data gathered (Garland 1991). This is possibly the reason that Antun et al. (2010) changed the five-point scale to a fourpoint scale to ensure a more intense response.

\section{Sample and data collection procedure}

The population of interest is MOP consumers in Gauteng Province, South Africa. Although Gauteng (City of Tshwane 
TABLE 1: Stages of item identification and description of important dining experience dimensions.

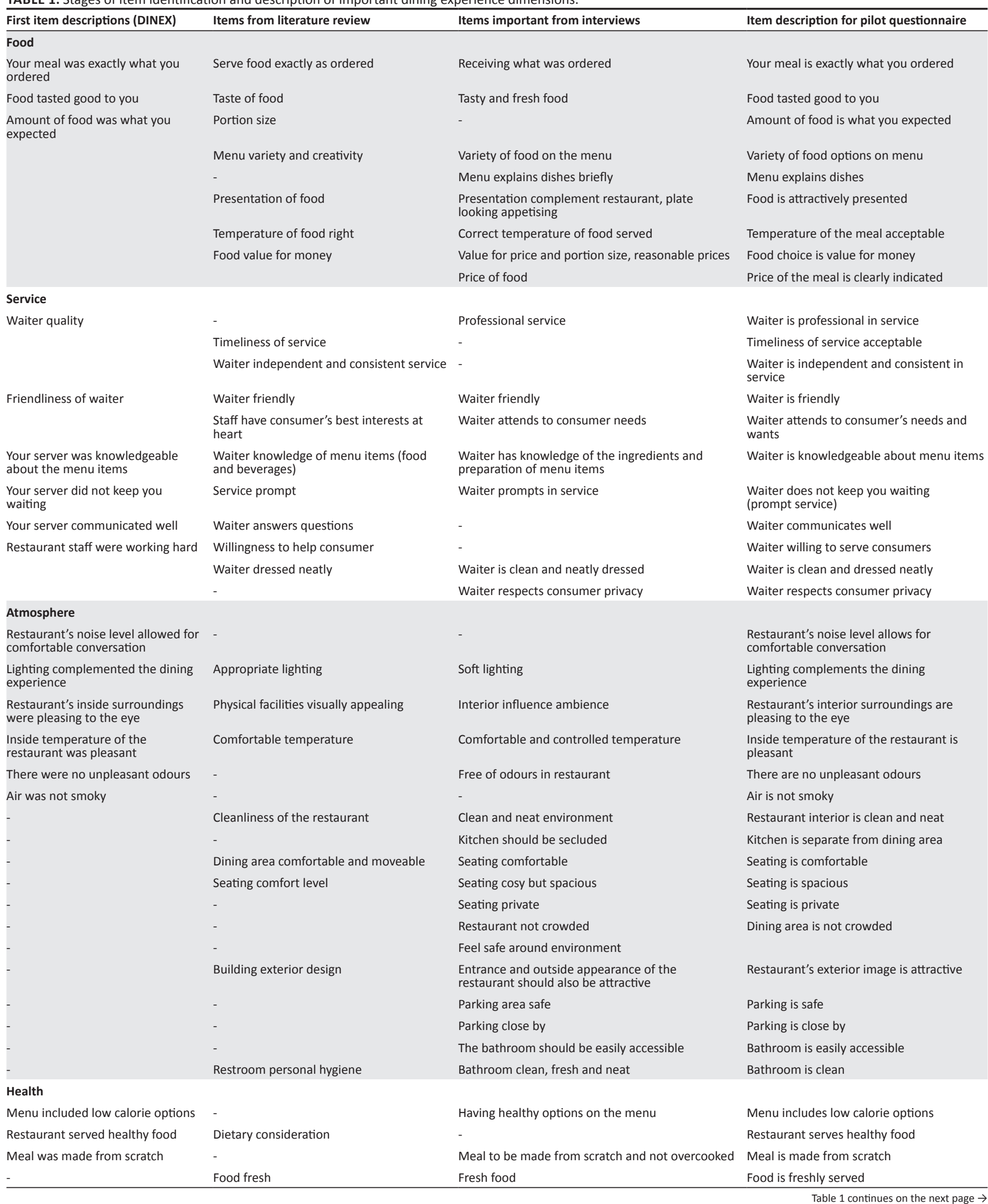


TABLE 1 (Continues...): Stages of item identification and description of important dining experience dimensions.

\begin{tabular}{lll}
\hline First item descriptions (DINEX) Items from literature review & Items important from interviews
\end{tabular}

Item description for pilot questionnaire

\section{Social experience}

Restaurant waiters know your

name

Restaurant staff had a sense of

what was going on in life

You knew the restaurant waiters'

names

Restaurant felt like a 'home away from home'

Server knows what you like to eat/

drink without you having to tell

them

You had a sense of belonging to

the restaurant

Other consumers in the restaurant

were like you

You didn't feel out of place

You were made to feel like family

at the restaurant

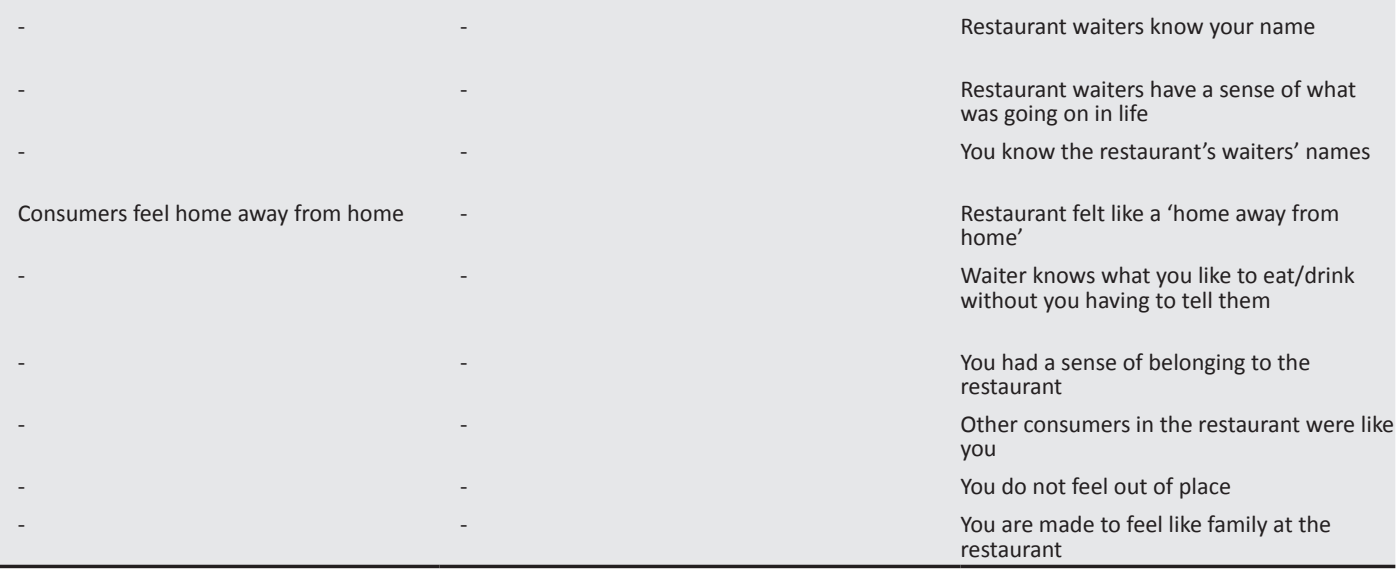

Source: Kleinhans, E.H., 2017, 'A framework of the dining experience dimensions for South Africa's middle of the pyramid consumers', Doctorate: Marketing, Tshwane University of Technology, Pretoria

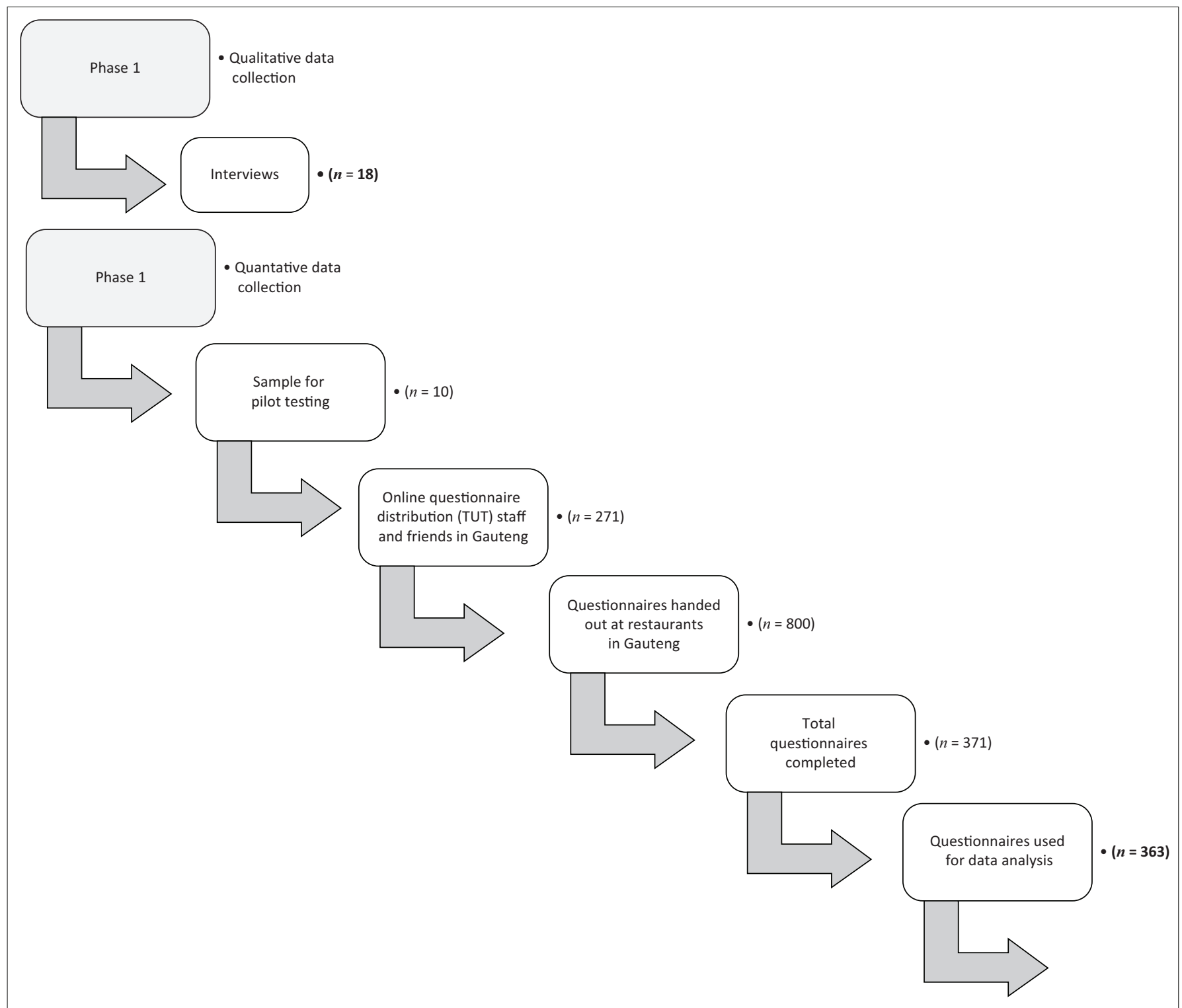

Source: Kleinhans, E.H., 2017, 'A framework of the dining experience dimensions for South Africa's middle of the pyramid consumers', Doctorate: Marketing, Tshwane University of Technology, Pretoria

FIGURE 1: Sample selection method for this study. 
and Johannesburg) is the smallest province by sample area, it is the most densely populated, with the largest population (13.2 million) (Statistics-SA 2015). To select a sample and determine the availability of the sample frame, sample control and accessibility of the respondents, the researcher used demographics and black consumers' expectations of restaurant dimensions to determine their dining behaviour. The specific criteria for inclusion in the sample, as set by SAARF-AMPS (2012), included black professionals (male and female), aged between 25 and 50, educated (matric or any post-matric qualification), earning a minimum salary of R12 000 per month, living in suburbs of Gauteng, falling into the young and mature couples, and young and mature families life stage and classified within the Living Standards Measure Segments 10-14.

The same criteria for sample selection were used for the interviews, pilot questionnaire, online questionnaire and questionnaires handed out at restaurants. Figure 1 displays the sample selection for the study.

A convenience sample (respondents that spend more than R1000 per month on dining out) using the snowball technique was used in the qualitative stage of the study, until the point of data saturation was reached. The findings from the data were used to validate the items selected for the questionnaire. The preliminary questionnaire was pilot-tested with five respondents from City of Tshwane and Johannesburg, respectively ( $n=10$ ) (Figure 1$)$, according to the set criteria for MOP consumers. The trial run was used to determine the analytical capability and effectiveness of the questionnaire as a research instrument. Maxwell (2013) and Strydom (2017) mention this as a suitable method for measuring and analysing the validity of the measuring instrument. The dining experience dimension questions were to be clearly stated and applicable to the respondents' choice.

In the quantitative data collection stage, an electronic questionnaire was distributed on Survey Monkey to the staff of a South African university according to their salary distribution, which formed part of the sample criteria to determine their needs and expectations of the dining experience of full-service restaurants. Full-service restaurants are defined as:

the guest is cared for by a server for both food and drinks, from the moment they sit down until the moment they leave, where they can order from a broad range of menu items and meal are paid for after they are eaten. (Hospitality and Tourism Management Training 2018)

A convenience sample was selected using the snowball technique, which South African researchers such as Henning, Van Rensburg and Smit (2011) confirm as being reliable. Each respondent was asked to recommend five friends outside the institution with similar dining needs and dining experience expectations (dining behaviour) for the second stage of data collection. The online respondents reached a plateau, and an alternative collection method was therefore implemented to achieve a reasonable number of respondents. Consequently, data were collected from identified full-service restaurants and coffee shops in Gauteng Province (City of Tshwane and Johannesburg) that were willing to participate in the study. The researcher used full-service restaurants and coffee shops because previous research had identified such establishments as the places where high-income South African consumers tend to dine for their 'luxury service' and convenience (Naudé \& Rudansky-Kloppers 2016). The researcher handed out 800 questionnaires to a convenience sample of MOP consumers. A total of 371 questionnaires were received, of which 363 could be used for analysis. The rule of thumb for factor analysis indicates a sample of 300 respondents, or five respondents per variable (O'Reilly \& Parker 2012). Van Voorhis and Morgan (2007) suggest the following guide for sample size: 50 is poor, 200 is fair, 300 is good and 500 is very good. The sample size was thus well within the range of representation for the selected MOP market segment.

\section{Data analysis}

The IBM SPSS program (version 22) was used to analyse the data. Of the 363 respondents, just over half $(50.7 \%, n=184)$ of the sample were under the age of 36 years. The $46-50$-year age group $(5.8 \%, n=21)$ formed the smallest proportion of the sample. The respondents were approximately equally represented by females $(49.3 \%, n=179)$ and males $(50.7 \%$, $n=184$ ). More than $40 \%$ of the respondents were married, compared with just fewer than $30 \%$ who were single. The largest proportion of the respondents $(73.8 \%, n=286)$ had children. Average monthly household income was divided into seven income levels. More than a quarter of the respondents $(27.5 \%, n=100)$ earned R10 $000-\mathrm{R} 14$ 999. The rest of the respondents were distributed across the other income groups, with the smallest proportion falling into the R25 000 - R29 999 and R30 000 - R34 999 income groups. Almost a fifth of the respondents $(18.2 \%, n=66)$ spent R2000 or more on dining out per month.

To substantiate validity, exploratory factor analysis (EFA) with varimax rotation was applied to the 50 dining experience dimension items (as shown in Table 2). The factorability of the correlation matrix was investigated using Pearson's product-moment correlation coefficient. The correlation matrix demonstrated a number of coefficients of 0.3 and above. The overall Kaiser-Meyer-Olkin value was 0.812 with the original 50 items, and 0.888 with the 48 items used in the solution, which was well above the recommended minimum value of 0.6 (Kaiser 1974). The Bartlett's test of sphericity (Bartlett 1954) reached statistical significance of $P<0.001$. The correlation matrix was thus deemed factorable.

\section{Ethical considerations}

Ethical clearance was obtained from the Management Sciences Faculty Committee of Post Grad Studies and the Research Central Ethics Committee at Tshwane University of Technology (Reference number: FREC2014/10/026-MS). Ethical clearance was given for the research project - this article is only a part of the study. 
TABLE 2: Exploratory factor analysis for the reduced list of 48 dining experience dimension items (eight-factor solution) ( $n=363$ ). Dining experience dimension factors and items Factor loadings Commonalities

\section{Factor 1: Service}

21. Waiter communicates well

$\begin{array}{ll}0.839 & 0.763 \\ 0.818 & 0.768 \\ 0.802 & 0.696 \\ 0.748 & 0.718 \\ 0.730 & 0.653 \\ 0.658 & 0.601 \\ 0.653 & 0.630 \\ 0.578 & 0.640 \\ 0.552 & 0.568 \\ 0.446 & 0.614 \\ 0.445 & 0.689\end{array}$

20. Waiter does not keep you waiting (prompt service)

22. Waiter is willing to serve consumers

18. Waiter attends to consumers' needs and wants

19. Waiter is knowledgeable about menu items

23. Waiter is clean and dressed neatly

24. Waiter respects consumer privacy

16. Waiter is dependable and consistent in service

17. Waiter is friendly

14. Waiter is professional in service

15. Timeliness of service acceptable

Factor 2: Social

46. Waiter knows what you like to eat/drink without having to tell them

47. You have a sense of belonging to the restaurant

48. Other consumers in the restaurant are like you

42. Restaurant waiters know your name

43. Restaurant waiters have a sense of what is going on in life

44. You know the restaurant waiters' names

45. Restaurant feels like a 'home away from home'

49. You do not feel out of place

50. You are made to feel like family at the restaurant

0.824

0.807

0.785

0.753

0.724

0.715

0.684

0.666

0.631

Factor 3: food

12. Price of the meal is clearly indicated

11. Food choice is value for money

9. Food is attractively presented

10. Temperature of the meal is acceptable

3. Amount of food is what you expected

7. Variety of food options on menu

13. Food is freshly served

\section{Factor 4: Layout}

36. Dining area is not crowded

34. Seating is spacious

37. Restaurant outside image is attractive

35. Seating is private

32. Kitchen is separate from dining area

33. Seating is comfortable

$\begin{array}{ll}0.629 & 0.600 \\ 0.626 & 0.549\end{array}$

$0.626 \quad 0.542$

$\begin{array}{ll}0.597 & 0.471\end{array}$

$\begin{array}{ll}0.487 & 0.377\end{array}$

$\begin{array}{ll}0.467 & 0.568\end{array}$

$0.422 \quad 0.537$

\section{Factor 5: Restaurant health}

30. Air is not smoky

31. Restaurant interior is clean and neat

29. There are no unpleasant odours

28. Inside temperature of the restaurant is pleasant

0.750

Factor 6: Atmosphere

26. Lighting complements the dining experience

0.739

0.717

0.679

0.653

0.666

$\begin{array}{ll}0.710 & 0.635\end{array}$

$\begin{array}{ll}0.617 & 0.636\end{array}$

0.553

25. Restaurant's noise level allows for comfortable conversation

27. Restaurant's interior surroundings are pleasing to the eye

0.721

4. Menu includes low calorie options

5. Restaurant serves healthy food

$\begin{array}{ll}0.715 & 0.765 \\ 0.700 & 0.630 \\ 0.593 & 0.664\end{array}$

6. Meal is made from scratch

8. Menu explains dishes

40. Bathroom is easily accessible

39. Parking is close by

38. Parking is safe

0.729

0.668

0.667

\section{Results}

Table 2 reports the factor loading of all the items and indicates those items with values lower than 0.40 that were not interpretable for the study (Burns \& Bush 2014). Of the dining experience items, two (Q1 'meal is exactly what you ordered', Q2 'food tastes good to you') did not load sufficiently on any of the components. These items were excluded from the dining experience dimension factors and 48 items were retained. Only those items with a greater than one variance 
explained were retained. Composite factors were identified using factor loadings and factor scores for items loading on each factor. These composite factors served as the independent variables in subsequent analysis for the study and should be interpreted taking into consideration the item content of each factor.

The 48 items resulted in a 10-component solution based on Eigenvalues greater than 1.00 , which explained $66.293 \%$ of the cumulative variance in the data. The initial confirmatory factor analysis of the 10-component solution with 48 items from the exploratory principal component analysis fitted the data reasonably well. Factor 10 had only two items. Previous researchers (Antun \& Gustafsson 2005) confirm that a parsimonious model with fewer items would be more useful in surveying a real restaurant situation. Least factors also tend to improve the factor matrix. It was decided to force a solution with only eight factors, as shown in Table 2, which resulted in a solution explaining $61.739 \%$ of the variance in the data and a six-component solution with a variance of $55.592 \%$. Owing to the larger number of overlapping items in the six-component solution, the eight-component solution was used as the final solution. Some of the items did not fit in content-wise with the factor theme content in which they were grouped, while others overlapped with items under the same factor. The items with cross-loads were evaluated in the context of theory. Even though the loading was lower on the other factor, and the factor loadings were both greater than 0.4 (Burns \& Bush 2014), the factor was categorised according to where interpretability was best. Items Q14 'Waiter is professional in service' and Q15 'Timeliness of service acceptable', which fell under the food factor, were thus moved to the service factor. Item Q13 'Food is freshly served', which fell under the restaurant health factor, was moved to the food factor because of its applicability to that category. A similar procedure was performed in the study by Kruger, Saayman and Slabbert (2015), where some factors were retained as part of the alternative possibility. The resulting internal consistency remained acceptable for all the factors, as shown in Table 2.

At this point, a conclusion can be reached regarding the validity of the dining experience dimensions of the measuring instrument. The commonality between variables was relatively high, ranging from 0.377 to 0.768 . The 48 items yielded eight factors that were interpretable, namely food, service, atmosphere, layout, social connectedness, food health, restaurant health and accessibility. The renamed factors differ from the categories used in the questionnaire because of the grouping and characteristics of the items in the factors. They also differ from the original five factors proposed by Antun et al. (2010) and the items added after the interviews and used in the questionnaire, namely food (11 items), service (11 items), atmosphere (17 items), social (9 items) and health (2 items) (Table 1). Even though the factors seem to be different, it can be concluded that the atmosphere factor could be divided into subsections related to general atmosphere, layout and accessibility, as noted by Ryu and Jang (2008a). The health factor could likewise be divided into food and restaurant health. The overall patterns identified in the EFA were similar to those in the study of Antun et al. (2010), except the separation of layout and accessibility from atmosphere factor, and the split of health and food factor in the restaurant (Barber, Goodman \& Goh 2011).

The reliability of the questionnaire was determined by using item analysis with coefficient alpha measurement. Reliability indicates the accuracy and consistency of the measuring instrument and is measured using a reliability coefficient. To aid in interpretability, varimax rotation was used to establish a clearer separation of the components (Hair et al. 2010). Excluding factor loadings of less than 0.4 resulted in a simple structure (Thurstone 1947), with each of the eight components showing a number of strong loadings (Table 3).

The Cronbach's alpha coefficient was calculated for the dining experience dimensions of the questionnaire, yielding internal consistency reliability of at least 0.7 or higher, which is appropriate (Pallant 2010). The generally accepted lower limit for Cronbach's alpha is 0.70 , although it may decrease to 0.60 in exploratory research, as stated by MacCaullum et al. (2001). The Cronbach's alpha coefficient was calculated for each of the eight factors as well as for the overall scale. The results per factor are given in Table 3.

Each of the extracted components demonstrates acceptable internal consistency (above 0.6), as illustrated by the Cronbach's alpha coefficients listed in Table 3. The Cronbach's alpha coefficients ranged from 0.693 to 0.921 for the eight dining experience factors, all of which were significant at the

TABLE 3: Reliability statistics for the eight extracted components $(N=363)$.

\begin{tabular}{|c|c|c|c|c|c|c|c|c|}
\hline \multirow[t]{2}{*}{ Factors } & \multirow[t]{2}{*}{ Description } & \multirow[t]{2}{*}{ Number of items } & \multirow[t]{2}{*}{ Cronbach's alpha } & \multirow[t]{2}{*}{ Eigenvalue } & \multicolumn{2}{|c|}{$\%$ Variance } & \multirow[t]{2}{*}{ Mean } & \multirow[t]{2}{*}{ Standard deviation } \\
\hline & & & & & Before rotation & After rotation & & \\
\hline 1 & Service & 9 & 0.921 & 12.249 & 25.519 & 12.562 & 5.21 & 0.723 \\
\hline 2 & Social & 9 & 0.901 & 5.434 & 11.321 & 10.896 & 3.46 & 1.141 \\
\hline 3 & Food & 8 & 0.829 & 3.249 & 6.769 & 8.976 & 5.09 & 0.650 \\
\hline 4 & Layout & 6 & 0.866 & 2.317 & 4.827 & 8.441 & 4.71 & 0.885 \\
\hline 5 & Restaurant health & 5 & 0.815 & 1.936 & 4.034 & 5.988 & 5.24 & 0.710 \\
\hline 6 & Atmosphere & 3 & 0.807 & 1.628 & 3.392 & 5.118 & 4.80 & 0.862 \\
\hline 7 & Food health & 4 & 0.693 & 1.547 & 3.280 & 4.995 & 4.42 & 0.973 \\
\hline 8 & Accessibility & 4 & 0.714 & 1.246 & 2.597 & 4.764 & 5.14 & 0.726 \\
\hline Overall & All dimensions & 48 & 0.918 & - & 61.74 & 61.74 & - & - \\
\hline
\end{tabular}

Source: Kleinhans, E.H., 2017, 'A framework of the dining experience dimensions for South Africa's middle of the pyramid consumers', Doctorate: Marketing, Tshwane University of Technology, Pretoria 
alpha level of 0.1 (Hair et al. 2010). Orthogonal rotation was done to minimise correlation between the factors, and thus results in better interpretation after rotation. The final eight factors were food, service, atmosphere, layout, social, food health, restaurant health and accessibility. The factors displayed reliability, and it can be concluded that the multiple measurement items are highly reliable in measuring each item. These factors support the researcher's initial conceptualisation of the important dining experience dimensions. According to the mean scores, the dimensions ranged from the highest to the lowest in descending order of importance as follows: restaurant health, service, accessibility, food, atmosphere, layout, food health and social. There was more agreement among respondents regarding the importance of restaurant health (standard deviation $[\mathrm{SD}]=0.719$ ) than social $(\mathrm{SD}=1.141)$ as dining experience dimensions. The highest level of agreement was related to food $(\mathrm{SD}=0.651)$, and the lowest level of agreement was related to social ( $\mathrm{SD}=1.141)$ as dining experience dimensions. The health factor was extended to the restaurant, which is not entirely unexpected, as the importance of health issues in restaurants was supported by Sulek and Hensley (2004) and Barber and Scarcelli (2010). The layout of the interior of the restaurant was also added as a separate factor. As confirmed by Ryu and Jang (2008b), the spatial layout and seating comfort have an immediate effect on consumers' perceptions of quality, pleasure and excitement as well as an unconscious effect on the intention of the consumer to return in future. It can be concluded that the reliability of the questionnaire was acceptable.

\section{Discussion}

The eight underlying dimensions (service, social, food, layout, restaurant health, atmosphere, food health and accessibility) are independent variables that influence MOP consumers in their decision-making with respect to dining out, but each dining experience dimension has a particular level of importance. The subscales for the extracted components were obtained by calculating the mean of the item loading on each of the subscales, as shown in Table 3. The most important dining experience dimension was restaurant health, and social was the least important.

This study noted both similarities and differences in comparing the results with the dining experience dimensions of importance in the study of Antun et al. (2010) (DINEX), and with TANGSERV (Baloglu, Mao and Busser (2010) and several South African studies (Kruger \& Saayman 2016; Mhlanga, Hattingh \& Moolman 2015; Mhlanga \& Tichaawa 2016). Restaurant health was found to be the most important dining experience dimension in this study, but it was accorded lesser importance in the original DINEX (Antun et al. 2010), and did not feature as important in other South African studies as well (Mhlanga et al. 2015; Mhlanga \& Tichaawa 2016). Moreover, the South African studies (Kruger \& Saayman 2016) did not consider the importance of the social dining experience dimension, which was noted as being least important in this study and in DINEX. The
TANGSERV scale used by Baloglu et al. (2010) mentioned the importance of accessibility, but at a lower level of importance than in this study. The South African studies conducted at full-service restaurants, as in this study (Mhlanga 2015; Mhlanga, Moolman \& Hattingh 2013; Mhlanga \& Tichaawa 2016; Moolman 2011; Petzer \& Mackay 2014), emphasise the importance of food quality, service and ambience. This study found these dining experience dimensions to be of moderate importance, similar to the findings of Antun et al. (2010) in DINEX. The reported differences of this study may be because of different characteristics in the selected sample and to the types of restaurant categorised as full-service restaurants.

\section{Managerial implications}

Western developed markets are known to have ageing populations. However, the South African market includes a significant MOP market segment, which is a growing brandconscious group that tends to develop among young working adults. Marketers should therefore reconsider the dining behaviour of the MOP consumers, characterised by unique consumption needs, and thus have a potential impact of the total MOP market. More targeted marketing campaigns should focus on this group of consumers to understand how they continually shape decision-making as the MOP market segment.

This study highlighted that the expectations of MOP consumers should be related to particular dining experience dimensions of full-service restaurants. In this way, restaurateurs could improve (and even exceed) the particular consumer dining expectations. Because of the restaurant density in the Gauteng area, formal full-service restaurants should aim to differentiate themselves from other restaurant categories.

\section{Contribution to research}

The study is among the first to analyse full-service restaurants in different locations for the South African MOP market segment and to propose and confirm the implications for their expected dining experience dimensions. An in-depth evaluation of the literature (as shown in Table 1) regarding important dining experience dimensions was done and their influence on decision-making related to dining out was adapted so as to be specific to MOP restaurant users. It is important for the hospitality industry to understand that there are different dining experience dimensions according to MOP needs and expectations, and that these should be identified as clearly as possible.

Al Khattab and Aldehayyat (2011) confirmed that it is not feasible to measure the dining experience with a single assessment tool because the consumer is part of the experience. Therefore, the researcher used both interviews and questionnaires to determine MOP consumers' needs and expectations during the dining experience, and thus enriched the quality of research. The interviews made it possible to 
understand consumers' needs and expectations, whereas the questionnaire was able to clarify the multivariate effect of the dining experience dimensions of the selected group of consumers.

Apart from enriching the academic literature, this study also makes a contribution to science. The present study shows that particular quality dining experience dimensions that influence the MOP market segment in choosing a restaurant for a dining experience. The implications are thus not limited to restaurants of a particular origin. Restaurant health, service, accessibility and food are the most important dining experience dimensions, followed by the atmosphere, layout, food health and social dining experience dimensions as factors that might influence diners' expectations of a quality dining experience.

\section{Limitations}

In assessing the empirical study, the main limitation was that the sample frame could not be compiled on the basis of the web-based questionnaire alone. Further prospective respondents were therefore selected through a convenience sample approach among consumers at full-service restaurants. The sample used for data analysis in the present study (363 cases) exceeded the absolute minimum recommended sample size of between 200 and 400 (Van Voorhis \& Morgan 2007). Considering the number of estimated parameters in this study (50 dining experience items), the sample was relatively small. A larger sample size is recommended in future studies for more appropriate estimates in the study model.

Data from this study were collected only in Gauteng Province, using a convenience sample approach. The outcomes of this study can therefore not necessarily be applied to restaurants in other geographical areas of South Africa. The validity of the present study with respect to MOP consumers could be increased through a larger sample in different geographical areas.

Another limitation was that, in considering their expectations of a dining experience, the respondents might have focused on particular restaurants, irrespective of whether these were their favourite restaurants or not.

\section{Conclusion}

The study discussed MOP consumers' priorities with respect to food, service, atmosphere and social connectedness as predictors of a quality dining experience. The study shows that there is a positive relationship between the levels of tangible dimensions in the restaurant industry. Although the intangible dimensions are more important, the tangible dimensions also perform an important role. The study revealed a number of similarities with previous studies, as discussed in the previous section. It can be concluded that the restaurant industry needs to consider particular dining experience dimensions when offering a service to MOP consumers. If they would like to attract more of this segment, they need to focus on the aspects of importance under each dining experience dimension.

Despite the apparent homogeneity of the selected group of respondents in terms of the demographic factors of group, age, gender and geographical location, this study revealed that there were differences in their perceptions of the phenomena under investigation. The eight dining experience dimensions extracted from the factor analysis were valid and it was possible to use them as independent variables in subsequent analysis in the study. The most important dining experience dimension factors were restaurant health, followed by service, accessibility, food, atmosphere, layout, food health and social. Restaurants should not underestimate what consumers expect from a dining experience, and should thus concurrently monitor and compare their consumer dining experience expectations to strengthen consumer retention, as well as for long-term sustainability and the restaurant's reputation.

\section{Acknowledgements Competing interests}

The authors have declared that no competing interests exist.

\section{Authors' contributions}

E.H.K. is the main researcher, supported by C.K. who assisted with the questionnaire design and C.H.v.H. who contributed to the analysis of the results and conclusion.

\section{Funding}

This research received no specific grant from any funding agency in the public, commercial or not-for-profit sectors.

\section{Data availability statement}

Data sharing is not applicable to this article as no new data were created or analysed in this study.

\section{Disclaimer}

The views and opinions expressed in this article are those of the authors and do not necessarily reflect the official policy or position of any affiliated agency of the authors.

\section{References}

African Development Bank, 2011, The middle of the pyramid: dynamics of the middle class in Africa, viewed 05 April 2016, from https://www.afdb.org/en/documents/ document/market-brief-the-middle-of-the-pyramid-dynamics-of-the-middleclass-in-africa-23582.

Al Khattab, S.A. \& Aldehayyat, J.S., 2011, 'Perceptions of service quality in Jordanian hotels', International Journal of Business and Management 6(7), 226-233. https:// doi.org/10.5539/ijbm.v6n7p226

Andersson, C. \& Mossberg, S.S., 2004, 'The dining experience: Do restaurants satisfy customer needs?', Food Service Technology 4(4), 171-177. https://doi. org/10.1111/j.1471-5740.2004.00105.x

Antun, J.M., Frash, R.E., Costen, W. \& Runyan, R.C., 2010, 'Accurately assessing expectations most important to restaurant patrons: The creation of the DineEX scale', Journal of Foodservice Business Research 13(4), 360-379. https://doi.org/1 $0.1080 / 15378020.2010 .524539$ 
Antun, J.M. \& Gustafsson, C., 2005, 'Menu success: A menu analysis of awarded fine dining restaurants and private clubs', Journal of Culinary Science and Technology 4(4), 51-66. https://doi.org/10.1300/J385v04n04_05

Arora, R., 2012, 'A mixed method approach to understanding the role of emotions and sensual delight in dining experience', Journal of Consumer Marketing 29(5), 333-343. https://doi.org/10.1108/07363761211247451

Asia Development Bank, 2010, The rise of Asia's middle class: Key indicators for Asia and the Pacific, viewed 10 April 2016, from https://www.adb.org/sites/default/ files/publication/27726/special-chapter-02.pdf.

Baloglu, S., Mao, Z. \& Busser, J., 2010, 'What really brings them back? The impact of tangible quality on affect and intention for casual dining restaurant patrons", International Journal of Contemporary Hospitality Management 22(2), 209-220. https://doi.org/10.1108/09596111011018197

Barber, N., Goodman, R.J. \& Goh, B.K., 2011, 'Restaurant consumers repeat patronage: A service quality concern', International Journal of Hospitality Management 30(2) 329-336. https://doi.org/10.1016/j.ijhm.2010.08.008

Barber, N. \& Scarcelli, J.M., 2010, 'Enhancing the assessment of tangible service quality through the creation of a cleanliness measurement scale', Managing Service Quality 20(1), 70-88. https://doi.org/10.1108/09604521011011630

Bartlett, M.S., 1954, 'A note on the multiplying factors for various chi-square approximations', Journal of the Royal Statistical Society 16(2), 296-298. https:// doi.org/10.1111/j.2517-6161.1954.tb00174.x

Bevan-Dye, A., Garnett, A. \& De Klerk, N., 2012, 'Materialism, status consumption and consumer ethnocentrism among black generation $Y$ students in South Africa', African Journal of Business Management 6(16), 5578-5586. https://doi org/10.5897/AJBM11.1803

Bowen, G.A., 2005, 'Preparing a qualitative research-based dissertation: Lessons learned', The Qualitative Report 10(2), 208-222.

Burns, A.C. \& Bush, R.F., 2014, Marketing research, 7th edn., Pearson, Boca Raton, FL.

Business Tech, 2016, Black versus white household spending in South Africa, viewed 19 September 2018, from https://businesstech.co.za/news/...white-vs-blackhousehold-spending-in-south-africa/.

Chickweche, T. \& Fletcher, R., 2014, 'Rise of the middle of the pyramid in Africa: Theoretical and practical realities for understanding middle class consume purchase decision making', Journal of Consumer Marketing 31(1), 27-38. https:// doi.org/10.1108/JCM-10-2013-0729

Cresswell, J.W. \& Clark, V.L.P., 2011, Designing and conducting mixed methods research, Sage Publications, Los Angeles, CA.

Cronin, J. \& Taylor, S.A., 1992, 'Measuring service quality: A reexamination and extension', Journal of Marketing 56(July), 55-67. https://doi.org/10.2307/ 1252296

Day, J., Immelman, R. \& Roberts-Lombard, M., 2017, 'Choice factors of restaurant patrons in the marketing of restaurants in South Africa', Paper presented at the Global Business and Technology Association, Vienna, Austria, viewed 21 September 2017, from https://gbata.org/journal-of-global-business-andtechnology-jgbat/publications/.

Du Toit, E., 2011, Uncorking the emerging market, viewed 05 September 2017, from www.unileverinstitute.co.za.

Garland, R., 1991, 'The mid-point on a rating sale: Is it desirable?', Marketing Bulletin 2(3), 66-70

Gerdes, J., Stringam, B. \& Brookshire, R., 2008, 'An integrated approach to assess qualitative and quantitative consumer feedback', Electronic Commerce Research 8(4), 217-234. https://doi.org/10.1007/s10660-008-9022-0

Goldberg, R.H., 2011, 'Determining consumer ethnocentrism and lifestyle among Black Diamonds in Sandton', Master of Commerce dissertation, North-West University, Potchefstroom.

Goldberg, R.H. \& Jansen van Rensburg, L.R., 2013, 'Relationships between ethnocentrism and lifestyle dimensions among a targeted consumer segment in Sandton', Journal of Contemporary Management 10(1), 362-383.

Hair, J.F., Black, W.C., Babin, B.J. \& Anderson, R.E., 2010, Multivariate data analysis, 7 th edn., Pearson, Upper Saddle River, NJ.

Henning, E., Van Rensburg, W. \& Smit, B., 2011, Finding your way in qualitive research, 8th edn., Van Schaik, Pretoria.

Hennink, M., Hutter, I. \& Bailey, A., 2011, Qualitative research methods, Sage Publications, London.

Hospitality and Tourism Management Training, 2018, What is a full service restaurant? viewed 25 September 2018, from https://study.com/academy/lesson/what-is-afull-service-restaurant.html.

Jackson, T., 2016, 'Africa's rising middle class - And why it matters', NewAfrican viewed 01 May 2018, from https://newafricanmagazine.com/11558-2/.

Johnson, G.D., 2013, 'Does race really matter? Consumer identity and advertising effectiveness in post-apartheid South Africa', South African Journal of Business Management 44(2), 11-17. https://doi.org/10.4102/sajbm.v44i2.152

Kaiser, H.F., 1974, 'An index of factorial simplicity', Psychometrica 39(1), 31-36. https://doi.org/10.1007/BF02291575

Kivits, R.F., Stierand, M.B. \& Wood, R.C., 2011, 'The 4M model of the meal experience', Paper Presented at the Seventh International Conference on Culinary Arts and Science (ICCAS), Bournemouth, UK Bournemouth, 12-14 April, viewed 05 May 2018, from https://pure.nhtv.nl/...4m-model-of-the-meal-experience.

Kleinhans, E.H., 2017, 'A framework of the dining experience dimensions for South Africa's middle of the pyramid consumers', Doctorate: Marketing, Tshwane University of Technology, Pretoria
Kleinhans, E.H., Van Heerden, C.H. \& Kleynhans, I.C., 2016, 'A review of dining experience dimensions over two decades', African Journal of Hospitality, Tourism and Leisure 35(4), 1-27.

Kolk, A., Rivera-Santos, M. \& Rufin, C., 2014, 'Reviewing a decade of research on the "base/bottom of the pyrami"”' (BOP) concept', Business and Society Review 53(3), 338-377. https://doi.org/10.1177/0007650312474928

Korhonen, M., 2018, Factsheets: Measuring the South Africa's black (middle) class, viewed 04 April 2019, from https://africacheck.org/factsheets/factsheetmeasuring-south-africas-black-middle-class/.

Kravets, O. \& Sandikci, O., 2014, 'Competently ordinary: New middle class consumers in the emerging markets', Journal of Marketing 78(4), 44-50. https://doi. org/10.1509/jm.12.0190

Kruger, M. \& Saayman, M., 2014, 'Exploring South Africa's "black diamonds" at live music performances', Acta Commercii 14(1), 1-13. https://doi.org/10.4102/ ac.v14i1.222

Kruger, M. \& Saayman, M., 2016, 'The dining and tipping behaviour of Black South Africans: A segmentation approach', Southern African Business Review 20(1), 336-364. https://doi.org/10.25159/1998-8125/6055

Kruger, M., Saayman, M. \& Slabbert, E., 2015, 'Managing visitors' dining and retail experiences in South African national parks', South African Journal of Business Management 46(2), 43-53. https://doi.org/10.4102/sajbm.v46i2.90

Lappeman, J. \& Neethling, N., 2017, 'Aspiration in South Africa: A growing crisis', viewed 01 August 2018, from https://www.news24.com/Columnists/ GuestColumn/aspiration-in-south-africa-a-growing-crisis-20170516.

MacCaullum, R.C., Widaman, K.F., Preacher, K.J. \& Hong, S., 2001, 'Sample size in factor analysis: The role of model error', Multivariate Behavioral Research 36(4), 611-637. https://doi.org/10.1207/S15327906MBR3604_06

Mashaba, N. \& Wiese, M., 2016, 'Black middle class township shoppers: A shopper typology', International Review of Retail, Distribution and Consumer Research 26(1), 35-54. https://doi.org/10.1080/09593969.2015.1068827

Maxwell, J.A., 2013, Quantitative research design: An interactive approach, 3rd edn., Sage Publications, Thousand Oaks, CA.

Mhlanga, O., 2015, 'Electronic meal experience: A gap analysis of online Cape Town restaurant comments', African Journal of Hospitality, Tourism and Leisure 4(1), 1-11.

Mhlanga, O., Hattingh, Z. \& Moolman, H.J., 2015, 'Authenticity of a South African dining experience: Tourists perceptions of cuisine at Knysna Waterfront restaurants', African Journal of Physical, Health Education, Recreation and Dance 21(3:1), 755-767.

Mhlanga, O. \& Machingambi, S., 2016, 'The influence of demographic variables on consumers' expectations in restaurants in the Eastern Cape province of South Africa', African Journal of Hospitality, Tourism and Leisure 5(1), 1-21.

Mhlanga, O., Moolman, H.J. \& Hattingh, Z., 2013, 'Expectations and experiences of customers in formal service restaurants in Port Elizabeth', African Journal of Physical, Health Education, Recreation and Dance 19(4:2), 1111-1122.

Mhlanga, O. \& Tichaawa, T.M., 2016, 'What are the current factors affecting consumer selection criteria in formal full service restaurants in Port Elizabeth, South Africa?', African Journal of Hospitality, Tourism and Leisure 5(2), 1-11.

Moolman, H.J., 2011, 'Restaurant customer satisfaction and return patronage in a Bloemfontein shopping mall', Acta Commercii 11(1), 129-146. https://doi. org/10.4102/ac.v11i1.157

Namkung, Y. \& Jang, S., 2010, 'Service failure in restaurants. Which stage of service failure is the most critical?', Cornell Hotel and Restaurant Administration Quarterly 51(3), 323-343. https://doi.org/10.1177/1938965510364488

Naudé, P. \& Rudansky-Kloppers, S., 2016, 'Perceptions of customers regarding their expectations of service quality in South African full-service restaurants', International Business and Economics Research Journal 15(2), 55-67. https://doi. org/10.19030/iber.v15i2.9609

Ndanga, L.Z.B., Louw, A. \& Van Rooyen, J., 2010, 'Increasing domestic consumption of South African wines: Exploring the market potential of the "black diamonds"', Agricultural Economics Research Policy and Practice in Southern Africa 49(3) 293-315. https://doi.org/10.1080/03031853.2010.503373

O'Reilly, M. \& Parker, N., 2012, 'Unsatisfactory saturation: A critical exploration of the notion of saturated sample sizes in qualitative research', Qualitative Research 13(2), 190-197. https://doi.org/10.1177/1468794112446106

Opperman, C., 2010, 'Investigating the marketing of South Africa wine among the emerging black market of South Africa', MBA dissertation, University of Stellenbosch, Stellenbosch

Pallant, J., 2010, SPSS survival manual, 3rd edn., McGraw-Hill, New York.

Pantelidis, I.S., 2010, 'Electronic meal experience: A content analysis of online restaurant comments', Cornell Hospitality Quarterly 51(4), 483-491. https://doi. org/10.1177/1938965510378574

Parasuraman, A., Zeithaml, V. \& Berry, L.L., 1985, 'A conceptual model of service quality and its implications for future research', Journal of Marketing 49(Fall), 41-50. https://doi.org/10.1177/002224298504900403

Parsa, H.G., Self, J.T., Gregory, A. \& Kirti, D., 2012, 'Consumer behaviour in restaurants: Assessing the importance of restaurant attributes in consumer patronage and willingness to pay', Journal of Services Research 12(2), 29-56.

Petzer, D. \& Mackay, N., 2014, 'Dining atmospherics and food and service quality as predictors of customer satisfaction at sit-down restaurants', African Journal of Hospitality, Tourism and Leisure 3(2), 1-14. 
Pizam, A., Shapoval, V. \& Ellis, T., 2016, 'Customer satisfaction and its measurement in hospitality enterprises: A revisit and update', International Journal of Contemporary Hospitality Management 28(1), 2-35. https://doi.org/10.1108/ Contemporary Hospital
IJCHM-04-2015-0167

Potgieter, D., Wiese, M. \& Strasheim, A., 2013, 'Demographic differences in adult consumers' decision-making styles in Tshwane, South Africa', Journal of Family Ecology and Consumer Sciences 41(1), 12-31.

Raajpoot, N.A., 2002, 'TANGSERV: A multiple item scale for measuring tangible quality in food service industry', Journal of Foodservice Business Research 5(2), 109-127. https://doi.org/10.1300/J369v05n02_08

Reimer, A. \& Kuehn, R., 2005, 'The impact of servicescape on quality perception' European Journal of Marketing 39(7/8), 785-808. https://doi.org/10.1108/ 03090560510601761

Ryu, K. \& Jang, S., 2008a, 'DINESCAPE: A scale of customers' perception of dining environments', Journal of Foodservice Business Research 11(1), 2-22.

Ryu, K. \& Jang, S., 2008b, 'Influence of restaurants' physical environment on emotions and behavioral intention', The Service Industry Journal 8(8), 1151-1165. https:// doi.org/10.1080/15378020801926551

SAARF-AMPS, 2012, Demographics of the 10 SAARF LSM groups for SAARF AMPS Jan 11-Dec 11 and SAARF AMPS Jul 11-June 12, viewed 02 March 2018, from www. saarf.co.za.

Simpson, J. \& Ramogase, T., 2014, 4 Million and rising, viewed 27 March 2018, from http://www.unileverinstitute.uct.ac.za/uui/research/4-million-rising.

Statistics-SA, 2015, Mid-year population estimates: July 2015, viewed 01 October 2017, from www.statssa.gov.za.
Stevens, P., Knutson, B. \& Patton, M., 1995, 'DINESERV: A tool for measuring service quality in restaurants', Cornell Hotel and Restaurant Administration Quarterly 36(2), 56-60. https://doi.org/10.1177/001088049503600226

Strydom, H., 2017, Research at grass roots: For the social sciences and human service professions, 4th edn., Van Schaik Publishers, Pretoria.

Strydom, J., 2011, Introduction to marketing, 4th edn., Juta, Cape Town.

Sulek, J.M. \& Hensley, R.L., 2004, 'The relative importance of food, atmosphere, and fairness of wait: The case of the full service restaurant', Cornell Hotel and Restaurant Administration Quarterly 45(3), 235-249. https://doi.org/ $10.1177 / 0010880404265345$

Suri, H., 2011, 'Purposeful sampling in qualitative research synthesis', Qualitative Research Journal 11(2), 63-75. https://doi.org/10.3316/QRJ1102063

Thurstone, L.L., 1947, Multiple factor analysis, University of Chicago Press, Chicago, IL.

Van Loggerenberg, M., 2009, 'Word-of-mouth marketing to emerging black middle class women in South Africa', MBA dissertation, University of Stellenbosch, Stellenbosch.

Van Voorhis, C.R.W. \& Morgan, B.L., 2007, 'Understanding power and rules of thumb for determining sample size', Tutorials in Quantitative Methods for Psychology 3(2), 43-50. https://doi.org/10.20982/tqmp.03.2.p043

Venter, M., Chinomona, R. \& Chuchu, T., 2016, 'The influence of store environment on brand trust, brand satisfaction and brand loyalty among the black middle class', The Retail and Marketing Review 12(2), 46-58.

Wong, A., Mei, O., Dean, A.M. \& White, C.J., 1999, 'Analysing service quality in the hospitality industry', Managing Service Quality 9(2), 136-143. https://doi.org/ 10.1108/09604529910257920 